\title{
Role of larval distribution and abundance in overall life-history dynamics: a study of the prawn Penaeus semisulcatus in Albatross Bay, Gulf of Carpentaria, Australia
}

\author{
Christopher J. Jackson*, Peter C. Rothlisberg, Robert C. Pendrey \\ CSIRO Marine Laboratories, PO Box 120, Cleveland, Queensland 4163, Australia
}

\begin{abstract}
The distribution and abundance of Penaeus semisulcatus de Haan larvae in Albatross Bay was studied during the 6 yr from March 1986 to April 1992. The study is a component of an investigation into the causes of interannual recruitment variation. Protozoeae were found in a wide range of temperatures and salinities and in both the presence and absence of thermoclines and haloclines, although density of larvae was low in water warmer than $30^{\circ} \mathrm{C}$. Two distinct peaks of larval abundance were evident: from January to March (summer), and from August to November (spring). Firststage protozoeae were rarely found during summer, although later stages were common, which suggests either that they were less catchable in summer or that most summer spawning was outside the study area. Three extended cruises during 1987 found high densities of larvae as far as $120 \mathrm{~km}$ offshore; these larvae represent wasted reproductive output since they are beyond the zone of effective spawning. The annual variations in abundance of larvae were compared with the results of parallel CSIRO studies of other P. semisulcatus life-history stages in Albatross Bay. There is poor agreement between larval numbers and the population fecundity index (a measure of egg production), but a stronger match with densities of postlarvae in the Albatross Bay estuaries, particularly in summer. This indicates that variable rates of egg hatching and early larval survival may be important determinants of successful recruitment to the P. semisulcatus fishery.
\end{abstract}

KEY WORDS: Penaeid larval ecology $\cdot$ Recruitment $\cdot$ Interannual variation $\cdot$ Shrimp

\section{INTRODUCTION}

Penaeid prawns (= shrimp) have 4 distinct types of life cycle (Dall et al. 1990), defined by the habitats of each life stage. Penaeus semisulcatus de Haan has a Type 3 life cycle: it spawns offshore and the larvae develop there, while the juveniles develop in seagrass or algal beds, in inshore waters and the lower reaches of estuaries (Haywood et al. 1995).

The larval duration of penaeids is relatively short (about $3 \mathrm{wk}$ ) and complex, with non-feeding naupliar stages, herbivorous protozoeae and omnivorous myses and postlarvae (Dall et al. 1990). The larval ecology of

\footnotetext{
*E-mail: chris.jackson@marine.csiro.au
}

most of the commercially-important penaeids of the Gulf of Carpentaria has been studied on a Gulf-wide scale (Rothlisberg et al. 1985, 1987, Rothlisberg \& Jackson 1987, Jackson \& Rothlisberg 1994). Both the distribution and abundance of larvae were assessed every 2 mo. These studies were made possible by the development of a procedure for identifying prawn larvae to species, using discriminant analysis of morphological data derived from laboratory-reared larvae (Jackson 1986).

Of the 4 species of Penaeus studied (P. merguiensis de Man, $P$. esculentus Haswell, and $P$. semisulcatus de Haan P. latisulcatus Kishinouye), P. semisulcatus were the most abundant and widespread (Rothlisberg et al. 1987). Numbers of protozoeae were highest in the northwestern and southwestern Gulf. Even with sam- 
ples taken only every 2 mo, it was clear from the abundance of protozoeae that reproductive activity peaked twice: in about September, and in January to March. The peaks were most prominent in the northwestern Gulf, where the species is most abundant. Of the 4 species, $P$. semisulcatus spawned in the deepest water, mostly at $40 \mathrm{~m}$ but extending out to $70 \mathrm{~m}$ depth. Because of the long spawning season and broad geographic extent, the temperatures and salinities at which $P$. semisulcatus protozoeae were found had the greatest range $\left(21\right.$ to $30^{\circ} \mathrm{C}, 28$ to $\left.35 \mathrm{psu}\right)$.

The vertical migratory behaviour and resultant advective potential of penaeid larvae in the Gulf have also been studied (Rothlisberg 1982, Rothlisberg et al. 1983a, 1996). Results from recent models suggest the larvae may move as much as $100 \mathrm{~km}$ between the offshore spawning grounds and the inshore nursery habitats. Marked seasonal changes in advective direction, caused by the different phase relationships of the day/night larval behaviour patterns compared to the dominant tidal constants, were also found. The net result is that at certain times of the year advection is onshore and at others offshore. These changes in advective direction are thought to ultimately control the timing and magnitude of postlarval recruitment pulses in Penaeus merguiensis in the southeastern Gulf (Rothlisberg et al. 1985, Staples \& Vance 1985).

\section{Six-year CSIRO study in Albatross Bay, Gulf of Carpentaria}

Staff from CSIRO's Cleveland Marine Laboratories conducted a multi-disciplinary study of the biology of Penaeus semisulcatus in the Gulf of Carpentaria from 1986 to 1992 . The primary objective was to identify the main factors that control the recruitment, and hence the abundance, of prawns in the commercial fisheries of the northeastern Gulf. This was done principally by measuring the year-to-year variation in abundance of the main life history stages (eggs, larvae, juveniles and adults) in the Albatross Bay region, examining the links between the stages, and assessing how abundance is affected by changes in the environment (e.g. temperature, rainfall, food, water movement).

\section{Spawning ecology}

The reproductive dynamics of Penaeus semisulcatus in Albatross Bay were assessed using a population fecundity index (PFI), based on the abundance and fecundity of spawners (Crocos \& van der Velde 1995). The population dynamics are complex, with up to 3 cohorts of adults at different ages $(6,12$ and $18 \mathrm{mo})$ recruiting to the fishery and then moving into, out of, and back into the area. The resulting patterns of reproductive output from all 3 cohorts (as measured by the PFI) show, on average, a broad peak from August to February. The index varied from year to year, depending on the abundance and relative contributions of the different cohorts-resulting in some years having bimodality in reproduction (1986/1987 and 1989/1990, see Fig. 4 of Crocos \& van der Velde 1995). However, in most years, bimodality was not pronounced. The authors concluded that only a subset of the spawning population - the effective spawning population-contributes to the subsequent recruitment. The effective spawners are defined by seasonal spawning periods, spawner age and fecundity, the proximity of spawning areas to nursery grounds, and prevailing currents.

Recently, Crocos \& Coman (1997) showed that the reproductive output of Penaeus semisulcatus, as measured by larval production, varied with age and was not a simple linear relationship with fecundity. Larval production was the sum of several interacting factors, including fecundity, hatch-rate and larval survival. While younger (smaller) females had lower fecundity, older (larger) females had lower hatch and larval survival rates. The highest production of viable larvae is, therefore, by mid-sized, 12-mo-old females.

\section{Juvenile ecology}

Over the 6 yr study (1986 to 1992), there was a consistent bimodal seasonal distribution in the abundance of juvenile Penaeus semisulcatus in the estuary, but the magnitude of catches varied from year to year (Vance et al. 1996). Of all the biological and environmental variables measured in the study, the main factor in determining density of juvenile prawns was the number of postlarvae that settled on the seagrass beds. The factors that established the pattern of abundance of juveniles in the estuary, and ultimately recruitment patterns to the offshore fishery, were apparently factors acting outside the estuary. As Crocos \& van der Velde (1995) had found only a slight bimodality in PFI, Vance et al. (1996) suggested that variation in the abundance of larvae offshore is responsible for the subsequent bimodality in abundance of postlarvae in the estuary.

\section{Fishery management}

Penaeid prawns are the second most valuable fishery in Australia (ABARE 1995). Most of the catch comes from tropical Australia (the Northern Prawn Fishery) and $80 \%$ of that comes from the Gulf of Carpentaria (Somers 1994). The commercial catch comprises 6 spe- 
cies: the banana prawn Penaeus merguiensis (41\% by weight); the tiger prawns $P$. esculentus $(24 \%)$ and $P$. semisulcatus $(23 \%)$; endeavour prawns Metapenaeus endeavouri $(8 \%)$ and $M$. ensis $(3 \%)$; and the western king prawn P. latisulcatus (1\%).

The banana and tiger prawn fisheries are managed with gear restrictions, limited-entry licensing, and seasonal closures. The current closures for tiger prawns are intended to protect pre-spawning adults (Somers 1990). However, the current management models assume a single cohort of spawning and recruitment. It has recently become clear that in the eastern Gulf there are 2 recruitment periods (Crocos \& van der Velde 1995, Vance et al. 1996) but the relationship between the spawning stock and these recruitment periods is not well understood. A better understanding of the links between the reproductive activities and later life-history stages is needed to refine management models.

In this paper we describe the spatial and temporal abundance of Penaeus semisulcatus larvae over the 6 yr study, and discuss how this abundance relates to that of other life-history stages and to environmental parameters.

\section{METHODS}

Study area and sampling scheme. The study was conducted in Albatross Bay in the northeastern Gulf of Carpentaria, Australia. Sampling stations were located on a $6 \times 6$ nautical mile grid, in depths from 5 to $65 \mathrm{~m}$. Cruises of 3 to 5 nights duration were made from March 1986 to March 1992, centred on the dates of the

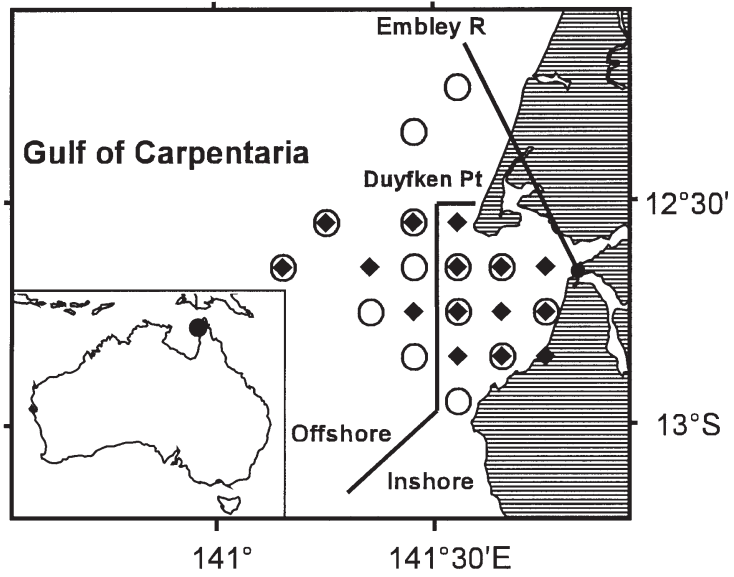

Fig. 1. Albatross Bay study area and sampling sites. Circles indicate plankton sampling sites during Phase 1 of the study, diamonds: sampling sites during Phase 2 (see 'Methods'). 'Inshore' and 'Offshore': classification of sampling sites, see 'Methods'. Inset: location of Albatross Bay in northern Australia

new moons (i.e., at 28 d intervals). Because 2 new moons occurred during December 1986, October 1989 and March 1992, 2 cruises were undertaken during these months (Table 1). A chartered prawn trawler was used to sample both larvae and adult prawns (Crocos and van der Velde 1995). A subset of stations was sampled for plankton (Fig. 1); this was generally done before towing the trawl nets. The positions of stations were fixed by radar and the Global Positioning System (GPS). Plankton sampling stations were classified as 'inshore' and 'offshore', approximately delineated by the $20 \mathrm{~m}$ depth contour (Fig. 1).

Table 1. Numbers of stations sampled on each cruise during study. Multiple numbers indicate repeated sampling on successive nights. I: inshore stations; O: offshore stations (Fig. 1)

\begin{tabular}{|c|c|c|c|c|c|c|c|c|c|c|c|c|c|c|}
\hline \multirow[t]{2}{*}{ Month } & \multicolumn{2}{|c|}{1986} & \multicolumn{2}{|c|}{1987} & \multicolumn{2}{|c|}{1988} & \multicolumn{2}{|c|}{1989} & \multicolumn{2}{|c|}{1990} & \multicolumn{2}{|c|}{1991} & \multicolumn{2}{|c|}{1992} \\
\hline & I & $\mathrm{O}$ & I & $\mathrm{O}$ & I & $\mathrm{O}$ & I & $\mathrm{O}$ & I & $\mathrm{O}$ & I & $\mathrm{O}$ & I & $\mathrm{O}$ \\
\hline Jan & & & 5 & 9 & 10,10 & 5 & 10,10 & 5 & 10,10 & 5 & 10,10 & 5 & 10,9 & 5 \\
\hline Feb & & & 5 & 9 & 10,9 & 4 & 10,8 & 5 & 10,10 & 5 & 10,8 & 5 & 10,5 & 5 \\
\hline Mar & 4 & 7 & 5 & 9 & 10,10 & 4 & 10,10 & 5 & 10,10 & 3 & 10,10 & 5 & 11,10 & 5 \\
\hline & & & & & & & & & & & & & 11,10 & 4 \\
\hline Apr & 3 & 9 & 5 & 9 & 10,10 & 5 & 20 & 5 & 9,10 & 4 & 10,10 & 5 & & \\
\hline May & 5 & 8 & 5 & 8 & 10,10 & 5 & 18 & 5 & & & & & & \\
\hline Jun & 4 & 8 & 5 & 9 & 9,10 & 5 & & & & & & & & \\
\hline Jul & 4 & 9 & 5 & 7 & 10,10 & 5 & & & & & & & & \\
\hline Aug & 4 & 7 & 5 & 9 & $10,10,10$ & 5 & $6,10,10$ & 4 & $10,10,10$ & 5 & $11,10,10$ & 5 & & \\
\hline Sep & 5 & 8 & 5 & 9 & $10,10,10$ & 5 & $9,10,10$ & 6 & $10,10,10$ & 5 & 11 & 5 & & \\
\hline Oct & 4 & 9 & 5 & 9 & $8,10,9$ & 5 & $10,10,10$ & 5 & $10,10,10$ & 5 & $1,10,10$ & 5 & & \\
\hline & & & & & & & $10,10,9$ & 1 & & & & & & \\
\hline Nov & 5 & 9 & 5 & 8 & $10,10,10$ & 5 & $10,10,9$ & 5 & 10,1 & 5 & $10,10,10$ & 5 & & \\
\hline Dec & 5 & 9 & 5 & 9 & 10,6 & 5 & & & & & 11,10 & 5 & & \\
\hline & 5 & 7 & & & & & & & & & & & & \\
\hline
\end{tabular}


The sampling schedule changed during the study. During the first phase of the project, from March 1986 to December 1987, both inshore and offshore stations were sampled once each cruise (Fig. 1, Table 1). During the second phase, from January 1988 to March 1992, sampling was changed to satisfy the needs of other (non-larval) components of the study. The effect of the changes was to intensify sampling effort at the inshore stations, particularly during the peak times of larval abundance. The number of inshore stations was increased (Fig. 1), and in addition stations were sampled repeatedly on successive nights. To compensate, fewer offshore stations were sampled and only once per cruise (Table 1). Finally, to contain the cost of the sampling program, no samples were taken at all in some months (June, July and December in 1989; May, June, July and December in 1990; May, June and July in 1991: Table 1).

Sampling procedures. A single plankton net, with a multi-vane steel kite-otter depressor attached $1 \mathrm{~m}$ below the net frame, was deployed with the vessel's winch. All plankton samples were taken at night by a stepped-oblique tow from surface to near-bottom, with 1 or 2 intermediate steps. A time-depth recorder, later replaced by a diver's maximum-depth indicator, was attached to the net frame to record the maximum sampling depth. Data from these instruments indicates that most samples reached within $2 \mathrm{~m}$ of the bottom, and over $80 \%$ were within $3 \mathrm{~m}$. There was no seasonal bias in the depth of the unsampled stratum below the maximum net depth. The cylinder-cone net had a $0.5 \times 0.5 \mathrm{~m}$ square mouth opening, a 10:1 filtering area to mouth area ratio, and was designed in excess of the 'green' water formulation of Smith et al. (1968). A flowmeter, calibrated after every cruise, was fitted in a corner of the mouth opening.

Until January 1988, 142 um plankton mesh was used. From February 1988, in order to sample greater water volumes and hence increase the precision of larval abundance estimates, a $250 \mu \mathrm{m}$ net was used instead. During the cruises in February and March 1988, both 142 and $250 \mu \mathrm{m}$ nets were deployed, side by side, in a 'bongo' style frame in order to compare catches. There was no significant difference in the density of prawn larvae in the catches, either for all protozoeae combined (paired Student's $t$-test: $t=0.397, \mathrm{df}=45, \mathrm{p}=0.6934$ ) or for Protozoea I only $(t=0.592, \mathrm{df}=45, \mathrm{p}=0.5567)$, but the larger mesh net caught, on average, only $52 \%$ of the total plankton biomass caught by the fine-mesh net. Biomass data from the earlier fine-mesh samples have been adjusted by this factor for better comparability with later samples.

Plankton tow time was generally between 5 and 10 min, depending on water clarity. Nets were hosed down thoroughly and the catch was fixed immediately with $4 \%$ buffered (sodium tetraborate) formaldehyde. We used a novel plankton net cod-end, designed to facilitate rapid and convenient concentration and transfer of the catch to sample jars (Pendrey 2000).

A submersible data logger (Yeo-Kal SDL ${ }^{\circledR}$ ) was used to record temperature and salinity profiles at each station, at 1 to $2 \mathrm{~m}$ intervals from surface to bottom. Surface temperature and salinity were estimated by averaging readings taken within $3 \mathrm{~m}$ of the surface, and bottom values were averages of data from within $3 \mathrm{~m}$ of the bottom. There are no temperature or salinity data available for any stations in cruises during March and December 1986, February 1988, October 1989 and March 1990 because of equipment failure.

Sorting and identification of larvae. Plankton samples were halved by a $270 \mathrm{~mm}$ diameter Folsom sample splitter (Longhurst \& Seibert 1967). One of the resulting fractions was dried for $24 \mathrm{~h}$ at $70^{\circ} \mathrm{C}$ and then weighed for biomass estimation. The remaining half was further subdivided until the settled volume was less than $40 \mathrm{ml}$; the final fraction was usually between a quarter and a sixteenth. The formaldehyde fixative in this fraction was replaced with $2 \%$ 2-phenoxyethanol in tap water for convenience and safety during sorting.

Penaeid larvae were sorted and ascribed to genera by the key of Jackson et al. (1989). Although larvae of all stages from first protozoea to early postlarvae were found in the samples, we present the findings for only the protozoeae, which were in much greater abundance.

Protozoeae were identified to species by comparing them with our reference collection of laboratoryreared larvae, using a method based on discriminant analysis of morphological data (Rothlisberg et al. 1983b, Jackson 1986, Jackson \& Rothlisberg 1994). While most species of Penaeus were represented in our original reference collection by larvae from at least 4 spawnings, there were only 2 spawnings of $P$. esculentus larvae (Jackson 1986). Because we recognise that this may not have represented the full range of morphological variation for this species, we have now enhanced the reference collection. This was done by adding further specimens of laboratory-reared $P$. esculentus larvae: 310 more Protozoea I, 269 more Protozoea II, and 239 more Protozoea III. These larvae originated from 4 spawnings. Therefore, our reference morphological database now comprises data for 16 morphological characters on each of 3134 larvae.

Our discriminant function identification method, described in detail by Jackson (1986), allocates the most likely identification for an unknown larva and calculates the probability associated with that identification. The identification is accepted only if its probability is greater than a predetermined threshold value; other- 
wise it remains unidentified. For this study we adopted an identification probability threshold of 0.75 . When applied to the known larvae in the reference collection, the proportion of Penaeus semisulcatus correctly identified ranged from $84.1 \%$ for Protozoea II to $89.2 \%$ for Protozoea I (Table 2). The proportion of reference-collection $P$. semisulcatus that could not be identified due to a classification probability being below the threshold value ranged from $16.3 \%$ for Protozoea III to $33.2 \%$ for Protozoea II (Table 2).

As a test of the effect of the new reference larvae on identification accuracy, we identified the larvae found during the study twice: first using the original reference database, and then again after including the additional Penaeus esculentus specimens. The main differences in results were that many larvae that could not be identified the first time were identified as $P$. esculentus the second time, and that some larvae identified as $P$. semisulcatus the first time were changed to P. esculentus the second time. With the larger reference collection, $28 \%$ of tiger prawn larvae were identified as $P$. esculentus; previously the figure was $6 \%$. The new result, the basis of this study, is similar to the relative abundances of the 2 tiger prawn species in commercial and scientific catches from the region (Somers 1994).

Standardization of larval density. The abundance of larvae in the water column below $1 \mathrm{~m}^{2}$ of sea surface (Kramer et al. 1972) was calculated by the formula:

$$
d=N D / F V
$$

where $d$ is larval density per $\mathrm{m}^{2}, N$ is the number of larvae in the sample, $D$ is the maximum sample depth (m) achieved during the stepped-oblique tow, $F$ is the fraction of the original sample actually sorted, and $V$ is the volume of water sampled $\left(\mathrm{m}^{3}\right)$, obtained from calibrated flowmeter readings.

\section{RESULTS}

\section{Water-column temperature and salinity}

Temperature peaked at about $31^{\circ} \mathrm{C}$ in early summer, before the wet season, generally during December. Minimum temperature in winter was 25 to $26^{\circ} \mathrm{C}$. There was little difference in water temperature between inshore and offshore stations (Fig. 2). Salinity in the inshore stations was normally from 34 to $36 \mathrm{psu}$, dropping in most years to 31 or 32 during the wet season (January to March) (Fig. 2). The wet season reduction in salinity was less pronounced offshore.

Offshore, a thermocline generally formed in early summer, with a surface to bottom temperature difference of 1.5 to $3^{\circ} \mathrm{C}$. Inshore, the thermocline formation was less pronounced and more short-lived (Fig. 3A). A halocline was usually evident during the wet season, at both inshore and offshore stations. The offshore halocline occurred 1 to 2 mo later than inshore (Fig. 3B). The wet season of 1988 was unusual in that salinity

Table 2. Penaeus spp. Results of applying discriminant function identification procedure to reference larvae of known identification, using identification threshold probability of 0.75 . Morphological data for each individual larva in the collection were used to calculate the most likely identification. Correct: percent of identifications that were correct; Unid.: percent of larvae that were unidentified due to classification probability below threshold value

\begin{tabular}{|c|c|c|c|c|c|c|c|c|}
\hline \multirow{2}{*}{ Stage } & \multicolumn{2}{|c|}{ P. merguiensis } & \multicolumn{2}{|c|}{ P. esculentus } & \multicolumn{2}{|c|}{ P. semisulcatus } & \multicolumn{2}{|c|}{ P. latisulcatus } \\
\hline & Correct & Unid. & Correct & Unid. & Correct & Unid. & Correct & Unid. \\
\hline Protozoea I & 96.7 & 19.5 & 88.5 & 38.4 & 89.2 & 31.6 & 97.7 & 5.1 \\
\hline Protozoea II & 97.5 & 12.9 & 84.9 & 46.5 & 84.1 & 33.2 & 100.0 & 0.0 \\
\hline Protozoea III & 96.7 & 5.3 & 93.7 & 19.7 & 85.0 & 16.3 & 99.1 & 0.0 \\
\hline
\end{tabular}




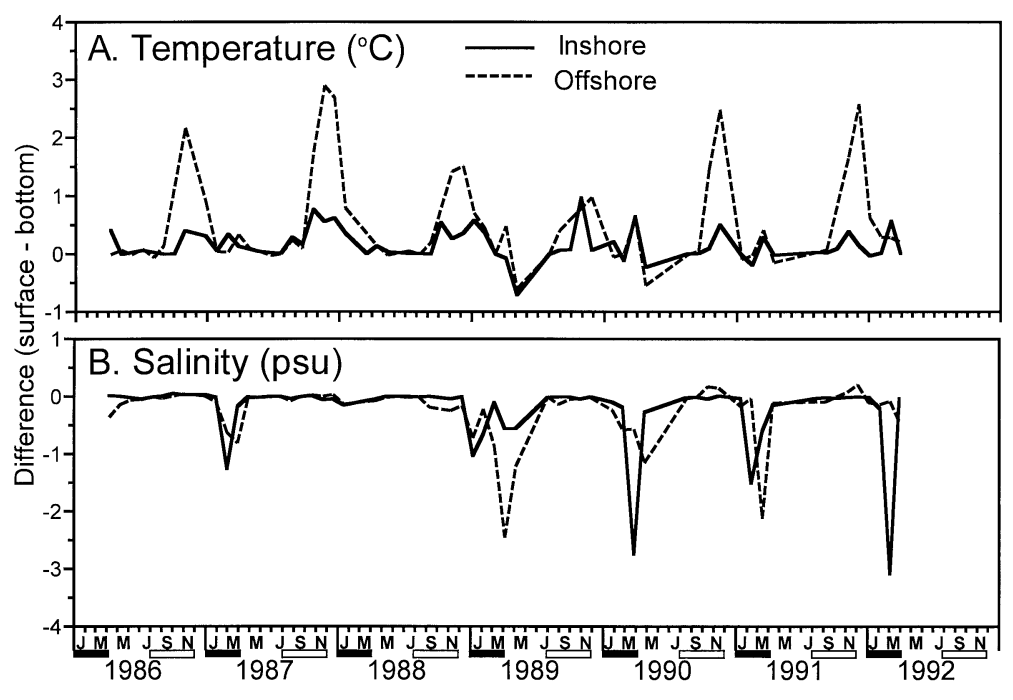

Fig. 3. (A) Temperature and (B) water-column salinity gradients in the Albatross Bay study area for 6 yr. Continuous line: inshore stations; broken line: offshore stations. Each graph shows the difference between surface $(\leq 3 \mathrm{~m})$ and bottom $(\leq 3 \mathrm{~m}$ from bottom). Black bars on $x$-axis indicate summer months (January to March); open bars: spring months (August to November)

remained high both inshore and offshore (Fig. 2) and no halocline developed (Fig. 3B).

\section{Relationship between larval abundance and other variables}

We examined the occurrence of Penaeus semisulcatus larvae with respect to water column temperature and salinity. Larvae were present over the whole range of temperatures sampled, both when the water column was well mixed (that is, surface temperature equal to bottom temperaturepoints near the diagonal line in Fig. 4A), and when a thermocline was present (points above the diagonal line). Similarly, larvae were present over the entire range of salinities encountered, both without a halocline (points near the diagonal line in Fig. 4B) and when a halocline was present (points below the diagonal line).

A multiple linear regression was performed to examine the effects of year, month, station, temperature, salinity, depth and water density (sigma- $t$ ) on log-transformed abundance of Penaeus semisulcatus larvae (Table 3). Year, month and station were treated as categorical variables. There were significant effects due to year (only for all protozoeal stages), month and station. The significant effect of year represents interannual variation in abundance, while the month effect represents seasonal variation. The significant effect of station represents spatial variation. Although there was no statistically significant effect of temperature on abundance of larvae, the data suggest a decline in abundance with increase in temperature (Fig. 5). No significant effects were found for salinity, sample depth or water density (sigma- $t$ ).

\section{Seasonal variation in abundance}

When each month's abundance of the 3 protozoeal stages pooled is averaged over $6 \mathrm{yr}$, with both inshore and offshore stations included, 2 seasonal peaks of abundance are clearly evident (Fig. 6): a short peak from January to March (late summer), and a more protracted peak from August to November (spring). The amplitudes of the peaks are similar. The abundance of larvae was low during December and January, which were the months when water temperature was above $30^{\circ} \mathrm{C}$ (Figs. $5 \& 6$ ). However, the pattern of abundance varied between years. For example, the December-January abundance minimum was close to zero in 1986/1987 and 1987/1988, but substantial numbers of larvae remained during these months in 1988/1989 (Fig. 7A).

First-stage protozoeae were rarely caught during summer, although they were quite common during spring (Fig. 7A). A paired $t$-test, comparing average density for the 2 seasons at each station in each year,
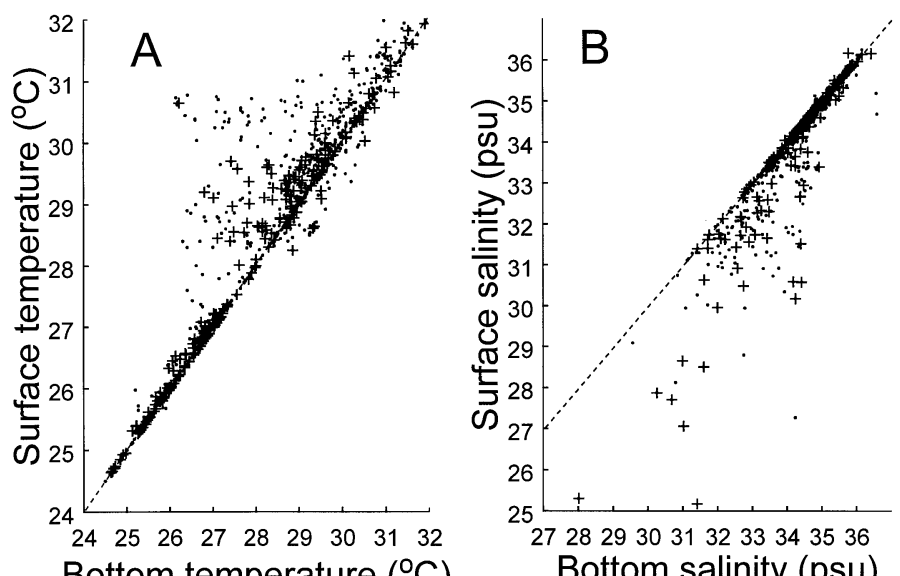

Bottom temperature $\left({ }^{\circ} \mathrm{C}\right)$

Bottom salinity (psu)

Fig. 4. Presence of Penaeus semisulcatus protozoeae in samples, compared with surface $(\leq 3 \mathrm{~m})$ and bottom ( $\leq 3 \mathrm{~m}$ from bottom) temperature (A) and salinity (B). (.) Stations with no larvae found; (+) larvae present. Diagonal line indicates zero gradient, i.e. surface temperature (A) or salinity (B) equal to that at bottom 
Table 3. Penaeus semisulcatus. Multiple regression of factors affecting larval abundance. Significance levels: ${ }^{*} \mathrm{p}<0.05$; ${ }^{* *} \mathrm{p}<0.01 ;{ }^{* * *} \mathrm{p}<0.001$

\begin{tabular}{|lrrr|}
\hline Source & df & SS & $F$ \\
\hline Protozoea I & & & \\
Year & 6 & 0.6060 & 1.923 \\
Month & 11 & 1.3933 & $2.411^{* *}$ \\
Station & 38 & 4.5469 & $2.278^{* * *}$ \\
Surface temperature & 1 & 0.0827 & 1.574 \\
Surface salinity & 1 & 0.0900 & 1.713 \\
Bottom temperature & 1 & 0.0064 & 0.121 \\
Bottom salinity & 1 & 0.0081 & 0.154 \\
Station depth & 1 & 0.0917 & 1.746 \\
Surface sigma- $t$ & 1 & 0.0890 & 1.6945 \\
Bottom sigma- $t$ & 1 & 0.0084 & 0.160 \\
All Protozoea & & & \\
Year & 6 & 6.074 & $3.691^{* *}$ \\
Month & 11 & 11.907 & $3.947^{* * *}$ \\
Station & 1 & 19.965 & $1.916^{* * *}$ \\
Surface temperature & 1 & 0.033 & 0.122 \\
Surface salinity & 1 & 0.048 & 0.177 \\
Bottom temperature & 1 & 0.012 & 0.045 \\
Bottom salinity & 1 & 0.008 & 0.029 \\
Station depth & 1 & 0.047 & 0.172 \\
Surface sigma- $t$ & 1 & 0.007 & 0.025 \\
Bottom sigma- $t$ & & & \\
& & & \\
\hline
\end{tabular}

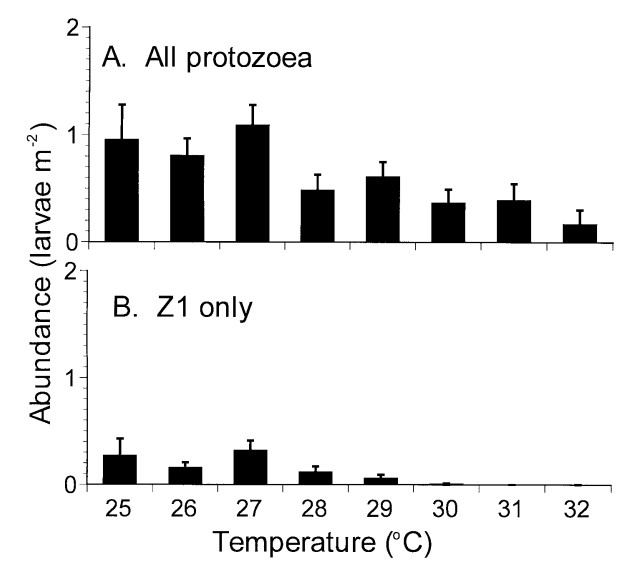

Fig. 5. Penaeus semisulcatus. Relationship between mean larval abundance (no. $\mathrm{m}^{-2}$ ) and temperature range

showed that this difference was highly significant $(\mathrm{p}<0.0001 ; \mathrm{df}=83)$.

\section{Interannual variation in abundance}

The larval abundance in the summer months of each year (January to March) was integrated to produce a single index of summer abundance, and similarly a spring index was calculated from the months August to November (Fig. 7B). Only the inshore stations were

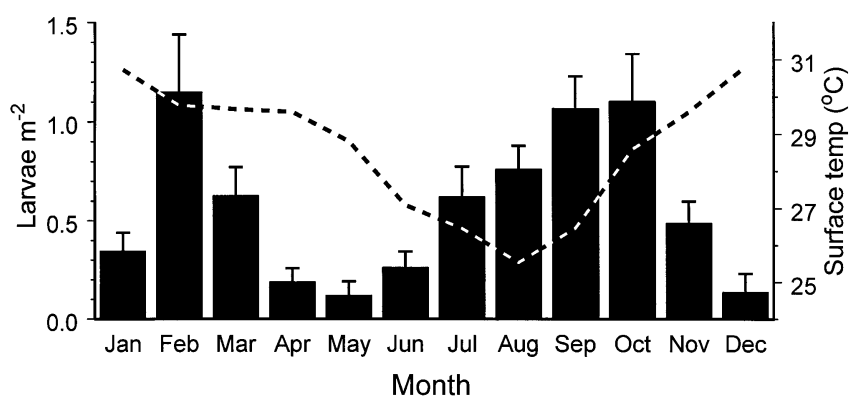

Fig. 6. Penaeus semisulcatus. Monthly abundance (no. $\mathrm{m}^{-2}$, $+1 \mathrm{SE}$ ) of protozoeae in Albatross Bay (histograms, left axis), and surface temperature at inshore stations (broken line, right axis)

included in these calculations, because larvae from further offshore are unlikely to contribute to subsequent recruitment. However, preliminary analyses indicated that even if all stations were included there was very little difference to the overall pattern of abundance.

Generally, abundance of larvae was highest in the first $3 \mathrm{yr}$ of the study, and lowest in the last $2 \mathrm{yr}$ (Fig. 7B). Total abundance for spring was usually higher than for summer in the same year, except in 1989 and 1991 when abundances in the 2 seasons were similar.

\section{Spatial patterns of larval abundance}

To examine the spatial distribution of larvae we averaged abundance at each station over the $6 \mathrm{yr}$, including only those stations that had been sampled at least 10 times. In summer (January to March), protozoeae of Penaeus semisulcatus were found throughout the study area, with no clear spatial pattern of abundance (Fig. 8A). These larvae were found at all regularly sampled stations. However, as already noted, first stage larvae were very rarely observed at this time. Only very low numbers were found at 3 stations west and southwest of Duyfken Point, and at the furthest station offshore (Fig. 8A). In spring (August to November), larvae were again found throughout the sampling area. At this time, Protozoea I larvae were also widespread, being found at nearly all stations (Fig. 8B).

\section{Offshore sampling}

Sampling was extended to $120 \mathrm{~km}$ offshore on 3 cruises during 1987. In May, no larvae were found anywhere except at 1 station south of Duyfken Point (Fig. 9A). During the July cruise, larvae of Penaeus 
semisulcatus were widely distributed. High densities were found from 40 to $120 \mathrm{~km}$ offshore, as well as at several of the regularly-sampled stations closer to the coast (Fig. 9B). By November, larvae had largely disap-
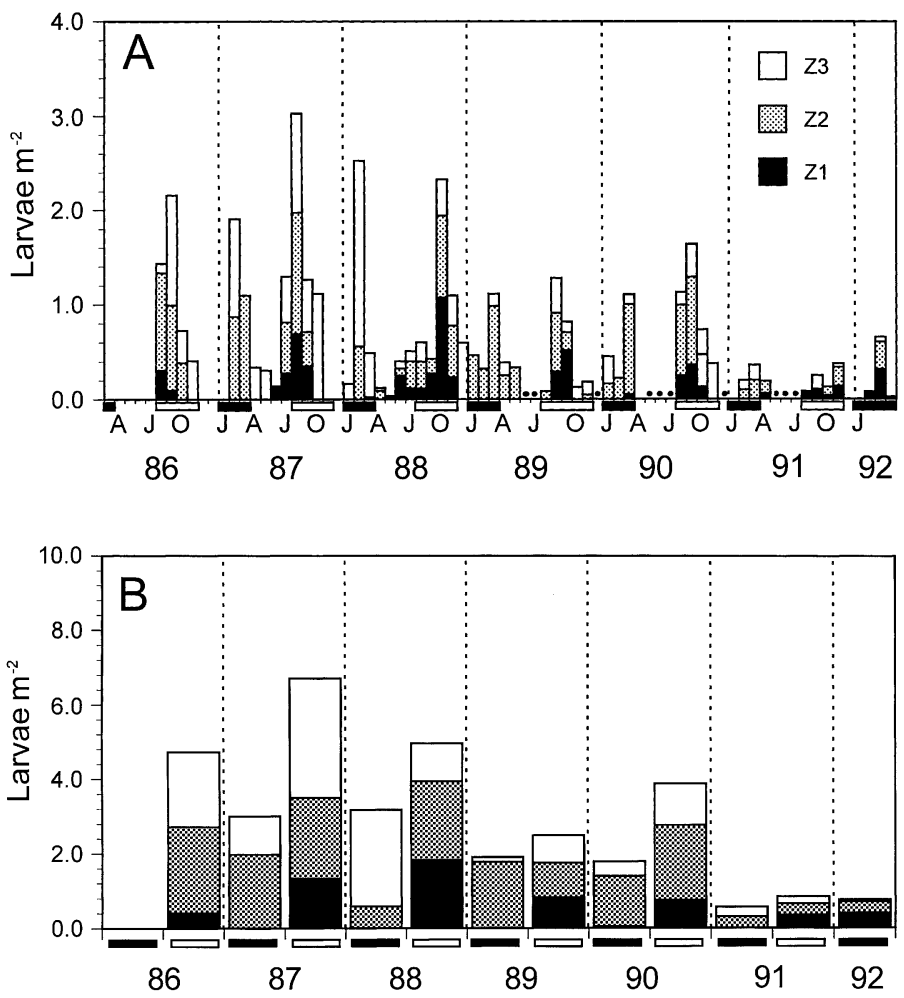

Fig. 7. Penaeus semisulcatus. Abundance (no. $\mathrm{m}^{-2}$ ) of protozoeae in Albatross Bay, 1986 to 1992, inshore stations only. Black bars on $x$-axis indicate summer months (January to March); open bars: spring months (August to November). Z1: Protozoea I; Z2: Protozoea II; Z3: Protozoea III. (A) Monthly abundance; black dots on abscissa indicate months when no samples were taken. (B) Seasonal abundance peared from the study area, being captured only at a single station, about $100 \mathrm{~km}$ offshore (Fig. 9C).

\section{DISCUSSION}

\section{Relative abundance of different larval stages}

During the 6 yr of the study, we found very few firststage protozoeae in summer. In fact, averaged over all samples, the most common substage of Penaeus semisulcatus was Protozoea II $(45.5 \%)$, while $35.5 \%$ were Protozoea III and only $18.9 \%$ were Protozoea I. Even during the spring abundance peak (when averaged over all $6 \mathrm{yr}$ ), only $25.8 \%$ of $P$. semisulcatus were Protozoea I. We had expected Protozoea I to be the most abundant substage found, with mortality reducing the abundance of later substages (each substage lasts about 24 h: Dall et al. 1990). However, Protozoea I are significantly under-represented in our samples, indicating they were not as catchable as later substages.

The most likely explanation for the small numbers of Protozoea I captured relates to their vertical distribution in the water column. Although our steppedoblique sampling strategy was designed to catch larvae throughout the water column, the effectiveness of this technique depends on the operator's skill in judging the length of wire to deploy while lowering the net to the bottom. Also, in rough weather the net is more likely to touch bottom if the operator misjudges, so operators tended to be conservative in such weather. Consequently, only half the tows reached within $1 \mathrm{~m}$ of the bottom, so it was therefore common for a significant bottom stratum of water to remain unsampled. Rothlisberg (1982) found that early protozoea larvae remain close to the bottom for most of the day and night, and the nightly migrations toward the surface became more
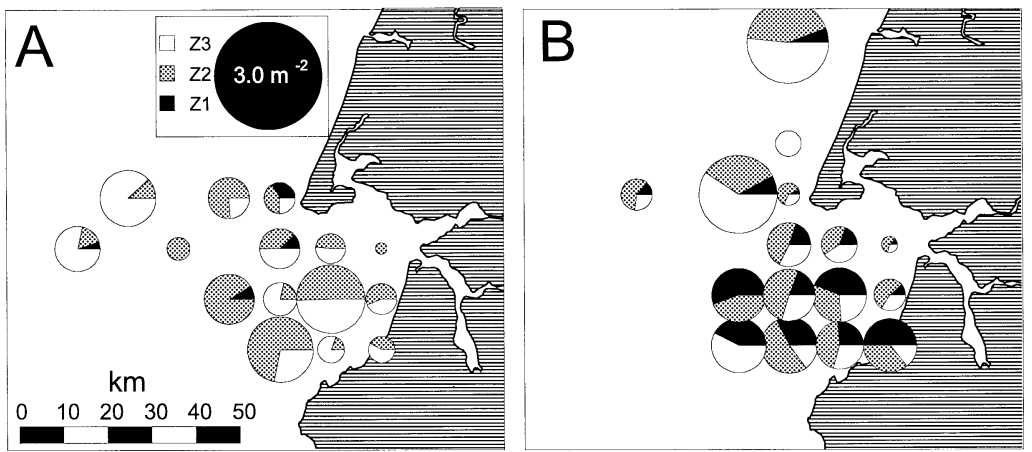

Fig. 8. Penaeus semisulcatus. Mean abundance, over $6 \mathrm{yr}$, of protozoeae (no. $\mathrm{m}^{-2}$ ) at sampling stations in Albatross Bay. (A) Summer abundance (January to March); (B) spring abundance (August to November). The results shown are only for stations that were sampled more than 10 times during the study. Z1: Protozoea I; Z2: Protozoea II; Z3: Protozoea III pronounced as larvae developed. This probably explains the relatively lower catches of Protozoea I in our samples throughout the year: these larvae may have mostly remained beneath the plankton nets, even at the maximum sampled depth. However, the absence of Protozoea I in summer remains to be explained. There was no seasonal bias in the extent of the unsampled bottom stratum of water, so this cannot have contributed directly. Rothlisberg suggested that the tendency of early larvae to remain at depth was correlated with ambient light levels; it is also possible that the extent of diurnal vertical 

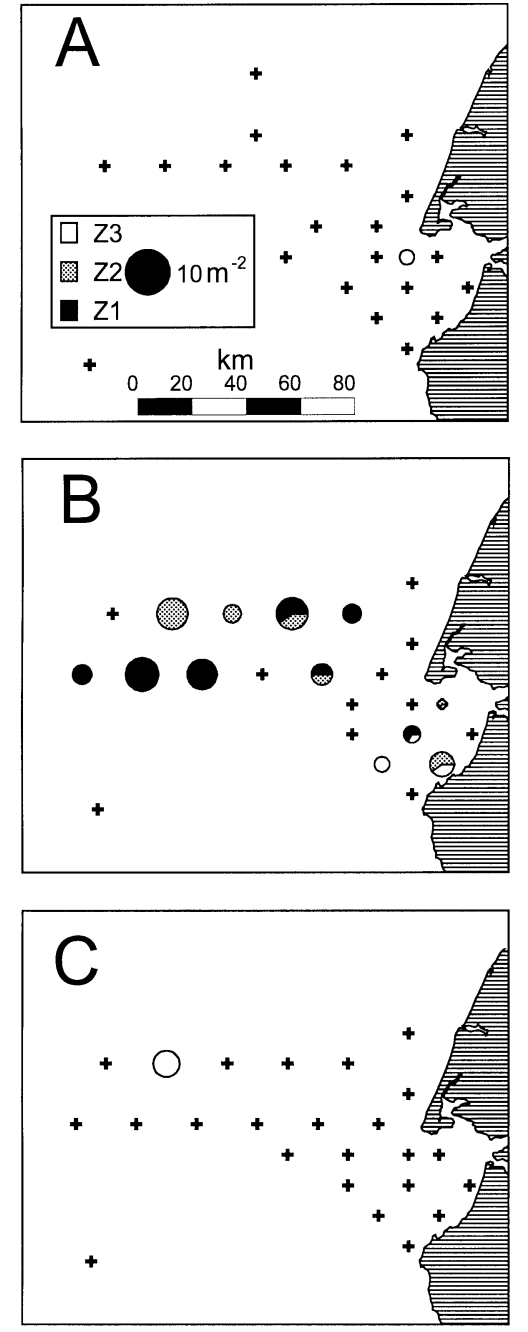

Fig. 9. Penaeus semisulcatus. Mean abundance of protozoeae (no. $\mathrm{m}^{-2}$ ) at distances up to $120 \mathrm{~km}$ offshore. (A) May 1987; (B) July 1987; (C) November 1987. (+) Sampling stations where no larvae were found; Z1: Protozoea 1; Z2: Protozoea 2; Z3: Protozoea 3

migration may be influenced by other seasonal factors. We suggest this is the most likely reason for the seasonal variation in Protozoea I abundance.

Another possibility, although one we consider less likely, is that the Protozoea II and III larvae we observed in summer may have been spawned outside the study area. Although the main part of the Penaeus semisulcatus fishery in the northeastern Gulf of Carpentaria is contained within our study area, there are significant populations of this species further south (Somers 1994). If these prawns were the main spawners in summer, and the currents at that time created appropriate larval advection patterns, larvae could have grown beyond the Protozoea I substage before arriving in our study area. Recent models of cur- rents and larval advection potential in the Albatross Bay region (Rothlisberg et al. 1996) confirm that, with the currents prevailing in March, larvae spawned up to $30 \mathrm{~km}$ south of the present study area could recruit into the Albatross Bay river system.

We are confident that a third possibility, that the smallest substages were escaping through the plankton net mesh, was not occurring. The densities of larvae in the samples taken with the $142 \mu \mathrm{m}$ mesh (used during the first $2 \mathrm{yr}$ ), and $250 \mu \mathrm{m}$ mesh (used afterwards) were not significantly different when compared in side-by-side trials at the time the change was made. The larger mesh size was therefore equally effective at retaining the smallest larval substages.

\section{Seasonality of larval abundance}

Averaged over the $6 \mathrm{yr}$ of the study, our results clearly indicate a bimodal spawning pattern for $\mathrm{Pe}$ naeus semisulcatus, with a large, protracted peak of spawning from August to November (spring) and a smaller, shorter peak in the late summer months of January to March. The bimodality, the periods of spawning, and the dominance of the spring spawning, are all in accordance with the 'tropical/subtropical' pattern of penaeid life history suggested by Dall et al. (1990). While it is to be expected that minor departures from the general pattern will occur occasionally, in fact the bimodal pattern is still evident in most years.

Seasonal low abundance of larvae could be due to either lack of spawning or larval mortality caused by seasonal factors. C. J. Jackson \& M. A. Burford (unpubl. data) studied the combined effects of temperature and salinity on the growth and survival of Penaeus semisulcatus larvae in the laboratory. Although the results clearly indicated that the normal salinity range in Albatross Bay was unlikely to affect growth or survival of $P$. semisulcatus larvae in nature, the effect of temperature was less clear. Survival of larvae was significantly reduced above $29^{\circ} \mathrm{C}$ in 1 experiment; however, this finding was not confirmed in 2 subsequent experiments.

The negative association found in this study between larval abundance and water temperature, with C. J. Jackson \& M. A. Burford's (unpubl. data) suggestion of possible lower survival due to high temperature, together may suggest that high temperature does limit the survival of Penaeus semisulcatus larvae, at least during abnormally warm summers. However, this is not supported by our data: the warmest summers $(1987,1988)$ were also summers when larval abundance was high, while the coolest summer (1991) had the lowest larval abundance. 


\section{Spatial distribution of larvae}

Larvae of Penaeus semisulcatus were widely distributed within the study area during both spring and summer spawning seasons, indicating that spawning is also widespread. The 3 cruises that extended into deep offshore waters also found evidence of widespread spawning in waters up to $120 \mathrm{~km}$ offshore during July. The existence of these larvae supports previous studies that have suggested that maturing adult $P$. semisulcatus characteristically migrate during winter into deep water, returning to coastal waters in spring (Somers \& Kirkwood 1991, Crocos \& van der Velde 1995).

However, recent studies suggest that only larvae spawned within the inner Albatross Bay region (a zone approximately corresponding to our 'inshore' stations, see Fig. 1) are likely to migrate successfully to the juvenile nursery grounds (Rothlisberg et al. 1996). Therefore, many Penaeus semisulcatus larvae undoubtedly do not reach the nursery grounds because they were spawned beyond the limits of possible advection. When using abundance of larvae to study factors affecting recruitment of larvae into juvenile populations, it is important to consider the abundance only from areas which are within the possible advection zone (the 'effective spawners' concept of Crocos \& van der Velde 1995). For this reason we included only the inshore stations when summarising annual abundances, so these data could be compared with data for other life-history stages.

\section{Abundance of larvae compared to other life-history stages}

Our study is part of a $6 \mathrm{yr}$ multidisciplinary CSIRO project that concurrently examined the other stages of the Penaeus semisulcatus life cycle in Albatross Bay. Crocos \& van der Velde (1995) studied the reproductive dynamics of adult $P$. semisulcatus and estimated the population fecundity index (PFI), a measure of spawning potential. Vance et al. (1996) studied the abundance of benthic postlarvae and juveniles in the estuary systems of Albatross Bay.

More recently, the PFI model has been refined ( $\mathrm{P}$. Crocos, CSIRO, pers. comm.) by only including those data in the PFI calculation that originated from stations located within the 'advective envelope' (the advective envelope [Rothlisberg et al. 1996] defines the limited area from which larvae can potentially reach nursery grounds through advective processes).

Therefore, we have a rare opportunity to compare the abundance of successive life-history stages and thus investigate their relationships.
Seasonal comparisons

Compared with our results, there was limited evidence of bimodality in the original PFI model (Crocos \& van der Velde 1995). PFI was highest from August to November and remained significant until January or February. There was a suggestion of a secondary peak centred on January, but the evidence was not strong. The PFI during January/February was considerably lower than from August to November. However, the refined PFI model (P. Crocos, CSIRO, pers. comm.) demonstrates a much more pronounced bimodality: a broad peak in PFI from September to November, and a shorter peak in January and February. The peaks were similar in magnitude. This result is quite similar to the overall seasonal abundance of larvae.

Vance et al. (1996) did find a bimodal pattern of abundance of benthic Penaeus semisulcatus postlarvae. The main peak was from September to November and the secondary from March to April. Juveniles peaked at similar times, although the 2 peaks were much the same size. Therefore, the peak abundance of these life-history stages lagged the larval peaks by about 1 to 2 mo. This is consistent with estimates that penaeid larvae take 12 to $20 \mathrm{~d}$ to reach the first postlarval stage (Dall et al. 1990).

\section{Interannual comparisons}

When the relative magnitudes of PFI (Crocos \& van der Velde 1995), abundance of larvae (this study), and benthic postlarvae and juvenile abundances in the nearby estuary (Vance et al. 1996) are compared over the 6 yr of the study, mismatches are more evident than matches (Fig. 10).

Firstly, consider the spring cohort: the first 3 yr were average or below for PFI, while the last 3 yr were average or above (Fig. 10A); larvae showed the opposite pattern, with the first $3 \mathrm{yr}$ above average and the last 3 below (Fig. 10B). Larvae and benthic postlarvae showed slightly more agreement: 1986 and 1988 were slightly above average for both stages, and 1990 and 1991 were below average. However, 1987 and 1989 were years of strong mismatch (Fig. 10B,C).

Considering the summer cohort, PFI results were dominated by the very high value in 1990 (Fig. 10E), which was not evident for any other stage. Of the other years, 1987 to 1989 were all above average for larvae (Fig. 10F), while these years were the lowest for PFI (Fig. 10E). The summer patterns of relative abundance of larvae and benthic postlarvae showed the best agreement (Fig. 10G): average or above values in 1988 to 1990, and below average values in 1991 and 1992 . However, 1987 was again a year of strong mismatch, 


\section{Spring}
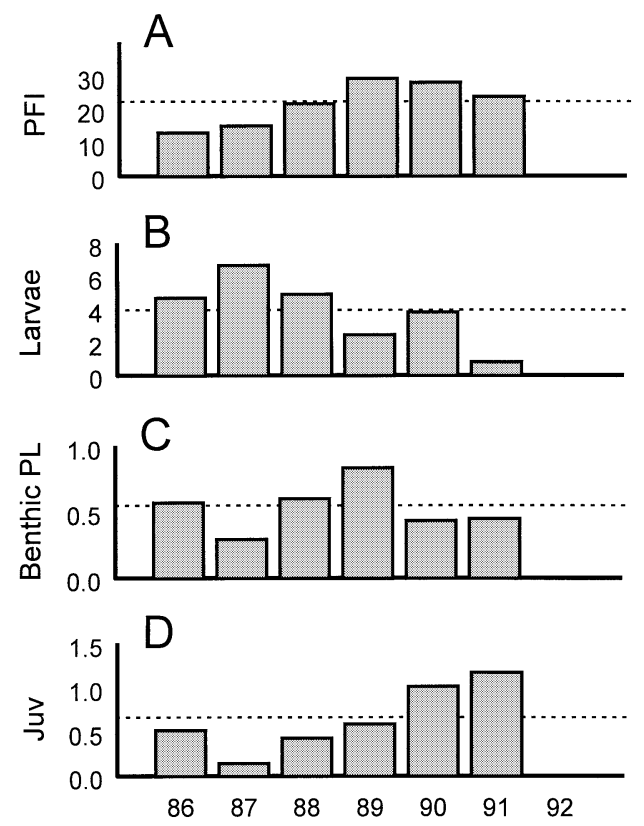

Summer
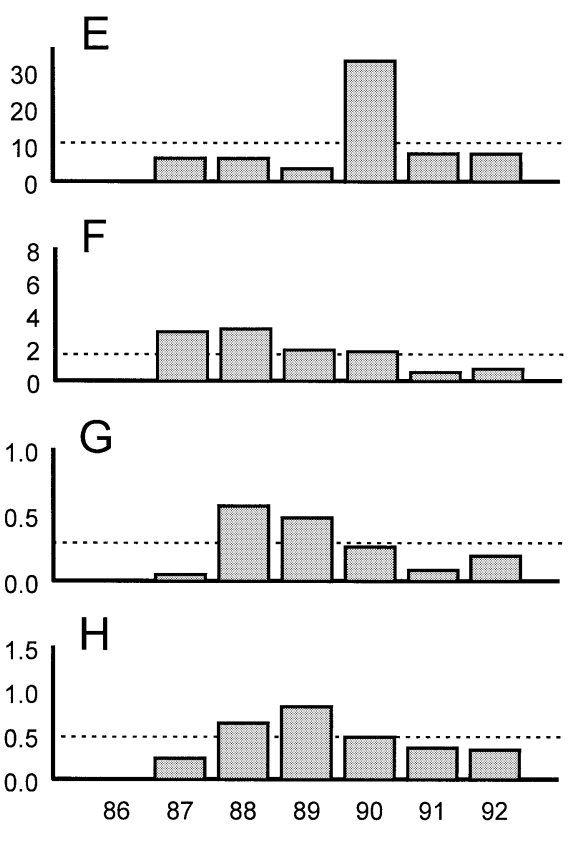

Fig. 10. Penaeus semisulcatus. Relative abundance of different life-history stages in Albatross Bay. Spring cohort abundance: (A) population fecundity index, PFI (from Crocos \& van der Velde 1995); (B) larvae (this study); (C) benthic postlarvae, PL (from Vance et al. 1996); (D) juveniles (from Vance et al. 1996). Summer cohort abundance: (E) PFI (from Crocos \& van der Velde 1995); (F) larvae (this study); (G) benthic postlarvae (from Vance et al. 1996); (H) juveniles (from Vance et al. 1996). Dotted lines indicate mean abundance over all years

being well above average for larvae while it was the lowest year of all for benthic postlarvae.

\section{Comparison of PFI and larvae}

Our results can demonstrate little relationship between larval abundance and previously published PFI, at either seasonal or annual time scales - although recent refinement of the PFI model does suggest a seasonal PFI pattern quite similar to that for larvae (P. Crocos, CSIRO, pers. comm.). As yet, the refined model has not been used to study interannual variation in PFI. While continuing enhancement of the PFI algorithm may improve agreement between PFI and larvae, there are also 2 reasons why PFI may be expected to differ from larval abundance.

Firstly, mortality of early larvae may vary due to physical conditions or predation. This study did not find a significant effect of salinity on larval abundance, and we have no information about larval predation. Although there is a significant negative association between larval abundance and water temperature, interannual variations in these parameters do not suggest a causative relationship. On the other hand, there is some evidence that nutrition may play an important role in limiting larval survival. Preston et al. (1998) suggested that high abundance of larval penaeids in Albatross Bay is linked to the absence of blooms of Trichodesmium spp. (cyanobacteria which occur frequently and in high densities in the study area: Burford et al. 1995). The effect on abundance of larvae may be due to toxicity or simply low nutritional value.

Secondly, PFI is a calculated index of spawning potential, and its relationship to successful spawning is unclear. Calculation of PFI incorporates a simple model of fecundity, which estimates the number of eggs based on spawner size. However, in a more recent study, Crocos \& Coman (1997) demonstrated that the effective reproductive performance of Penaeus semisulcatus is actually the combined result of spawning rate, egg production rate, hatching success and survival of earliest larval stages. These factors combined to produce the highest effective reproductive performance in 12-mo-old females: both younger and older prawns produce fewer viable larvae. This may mean that PFI overestimates larval production if either small or large prawns dominate the sample of spawners.

In summary, our results demonstrate links between abundance of larvae and subsequent abundance of benthic postlarvae in the Albatross Bay estuaries. This suggests that annual variability in spawning success or mortality of larvae before Protozoea I may be important determinants of recruitment success. 
On the other hand, published data for PFI do not show a strong relationship with the seasonal or interannual variation in abundance of Penaeus semisulcatus larvae. However, there is now some indication that more sophisticated selection of locations included in the PFI analysis might also tighten the link between larvae and PFI.

Acknowledgements. Peter Crocos and Tonya van der Velde assisted with field sampling, and Mair Beamish sorted the plankton samples and identified the larvae. Peter Crocos provided unpublished information about refinements to the PFI model, and both You-Gan Wang and Bill Venables helped with statistical analyses. The study was supported by grants 85/85 and 89/13 from the Fisheries Research and Development Corporation (FRDC, previously FIRTA). Peter Crocos, Neil Loneragan and Vivienne Mawson helped improve early drafts of the manuscript.

\section{LITERATURE CITED}

ABARE (1995) Australian Fisheries Statistics (1995). Australian Bureau of Agricultural and Resource Economics, Canberra

Burford MA, Rothlisberg PC, Wang Y (1995) Spatial and temporal distribution of tropical phytoplankton species and biomass in the Gulf of Carpentaria, Australia. Mar Ecol Prog Ser 118:255-266

Crocos PJ, Coman GJ (1997) Seasonal and age variability in the reproductive performance of Penaeus semisulcatus broodstock: optimising broodstock selection. Aquaculture 155:57-69

Crocos PJ, van der Velde TD (1995) Seasonal, spatial and interannual variability in the reproductive dynamics of the grooved tiger prawn, Penaeus semisulcatus de Haan, in Albatross Bay, Gulf of Carpentaria, Australia: the concept of effective spawning. Mar Biol 122:557-570

Dall W, Hill BJ, Rothlisberg PC, Staples DJ (1990) (eds) Biology of the Penaeidae. Advances in marine biology, Vol 27. Academic Press, London

Haywood MDE, Vance DJ, Loneragan NR (1995) Seagrass and algal beds as nursery habitats for tiger prawns (Penaeus semisulcatus and $P$. esculentus) in a tropical Australian estuary. Mar Biol 122:213-223

Jackson CJ (1986) Numerical identification of early larvae of four species of Penaeus, and factors affecting morphology of larval P. semisulcatus. MPh thesis, Griffith University, Brisbane

Jackson CJ, Rothlisberg PC (1994) Larval ecology and reproductive activity of Metapenaeus ensis and $M$. endeavouri in the Gulf of Carpentaria, Australia, assessed from the distribution and abundance of the protozoeal stages. J Plankton Res 16:219-231

Jackson CJ, Rothlisberg PC, Pendrey RC, Beamish M (1989) A key to genera of the penaeid larvae and early postlarvae of the Indo-west Pacific region, with descriptions of the larval development of Atypopenaeus formosus Dall and Metapenaeopsis palmensis Haswell (Decapoda: Penaeoidae: Penaeidae) reared in the laboratory. Fish Bull US Fish Wild Serv 87:703-733

Editorial responsibility: Otto Kinne (Editor), Oldendorf/Luhe, Germany
Kramer D, Kalin MJ, Stevens EG, Thrailkill JR, Zweifel JR (1972) Collecting and processing data on fish eggs and larvae in the California Current region. NOAA Tech Rep NMFS 370:1-38

Longhurst AR, Seibert DLR (1967) Skill in the use of Folsom's plankton splitter. Limnol Oceanogr 12:334-335

Pendrey RC (2000) A condensing codend for zooplankton nets. CSIRO Marine Research, Hobart (Divisional Report)

Preston NP, Burford MA, Stenzel DJ (1998) Effects of Trichodesmium spp. blooms on penaeid prawn larvae. Mar Biol 131:671-679

Rothlisberg PC (1982) Vertical migration and its effect on dispersal of penaeid shrimp larvae in the Gulf of Carpentaria, Australia. Fish Bull US Fish Wildl Serv 80:541-554

Rothlisberg PC, Jackson CJ (1987) Larval ecology of penaeids of the Gulf of Carpentaria, Australia. 2. Hydrographic environment of Penaeus merguiensis, $P$. esculentus, $P$. semisulcatus and P. latisulcatus zoeae. Aust J Mar Freshw Res 38:18-28

Rothlisberg PC, Church JA, Forbes AMG (1983a) Modelling the advection of vertically migrating shrimp larvae. J Mar Res 41:511-538

Rothlisberg, PC, Jackson CJ, Pendrey RC (1983b) Specific identification and assessment of distribution and abundance of early penaeid shrimp larvae in the Gulf of Carpentaria, Australia. Biol Bull 164:279-298

Rothlisberg PC, Jackson CJ, Pendrey RC (1985) Distribution and abundance of early penaeid larvae in the Gulf of Carpentaria, Australia. In: Rothlisberg PC, Hill BJ, Staples DJ (eds) Second Australian National Prawn Seminar NPS2. Cleveland, Australia, p 23-30

Rothlisberg PC, Jackson CJ, Pendrey RC (1987) Larval ecology of penaeids of the Gulf of Carpentaria. I. Assessing the reproductive activity of five species of Penaeus from the distribution and abundance of zoeal stages. Aust J Mar Freshw Res 38:1-17

Rothlisberg PC, Craig P, Andrewartha J (1996) Modelling penaeid prawn larval advection in Albatross Bay, Australia: defining the effective spawning population. Mar Freshw Res 47:157-168

Smith PE, Counts RC, Clutter RI (1968) Changes in filtering efficiency of plankton nets due to clogging under tow. J Cons Int Explor Mer 32:232-248

Somers IF (1990) Manipulation of fishing effort in Australia's penaeid prawn fisheries. Aust J Mar Freshw Res 41:1-12

Somers IF (1994) Species composition and distribution of commercial penaeid prawn catches in the Gulf of Carpentaria, Australia, in relation to depth and sediment type. Aust J Mar Freshw Res 45:317-335

Somers IF, Kirkwood G (1991) Population ecology of the grooved tiger prawn, Penaeus semisulcatus, in the northwestern Gulf of Carpentaria, Australia: growth, movement, age structure and infestation by the bopyrid parasite Epipenaeon ingens. Aust J Mar Freshw Res 42: 349-367

Staples DJ, Vance DJ (1985) Short-term and long-term influences on the immigration of postlarval banana prawns Penaeus merguiensis, into a mangrove estuary of the Gulf of Carpentaria, Australia. Mar Ecol Prog Ser 23:15-29

Vance DJ, Haywood MDE, Heales DS, Staples DJ (1996) Seasonal and annual variation in abundance of postlarval and juvenile grooved tiger prawns, Penaeus semisulcatus and environmental variation in the Embley River, Australia: a six yr study. Mar Ecol Prog Ser 135:43-55

Submitted: August 1, 1998; Accepted: September 14, 2000

Proofs received from author(s): March 16, 2001 